\title{
Influence of Organizational Resources and Structure on Business Continuity Management of Private Security Firms in Kenya
}

\author{
Richard Marisa ${ }^{1}$,, Daniel Oigo ${ }^{2}$ \\ ${ }^{1}$ Department of Business Studies, Jomo Kenyatta University of Agriculture and Technology, Nairobi, Kenya \\ ${ }^{2}$ Department of Business Administration and Management Science, Szent István University, Godollo, Hungary \\ Email address: \\ rmarisa@twentyfour.co.ke (R. Marisa), ogachdniel@gmail.com (D. Oigo) \\ ${ }^{*}$ Corresponding author
}

To cite this article:

Richard Marisa, Daniel Oigo. Influence of Organizational Resources and Structure on Business Continuity Management of Private Security Firms in Kenya. Journal of Human Resource Management. Vol. 6, No. 1, 2018, pp. 18-25. doi: 10.11648/j.jhrm.20180601.13

Received: January 9, 2018; Accepted: January 18, 2018; Published: February 17, 2018

\begin{abstract}
The concept of business continuity management (BCM) has gained wide acceptance in recent years and it is key for the survival of any contemporary organization during crisis. Therefore, modern organizations must reconsider the significance of creating awareness and being prepared for the unexpected. This is so because in the event a catastrophe happens, it may interrupt an organization's daily operations. Organizations should completely comprehend the significance of this idea and the effect it could have on the association. Sufficient and compelling activities and methods ought to be set up to address the association's business coherence dangers. The objective of this examination was to investigate the influence of organizational structure on BCM. The examination utilized two speculations Contingency Theory and Resource Based View Theory with the objective populace of the investigation being staff and different partners of private security associations. Stratified random sampling and purposive sampling will be employed to select the respondents. The findings from the study revealed that BCM emerged as the essential part to overall organization health that all sectors of business identify. BCM success depends on clearly defined strategic plans through planning by management. The strategic plans are laid down by the management of an organization which is defined by several elements in practice. The elements are categorically based on the organization structure, style, system and resources. Therefore, business continuity management is a combination of different elements of the organization.
\end{abstract}

Keywords: Business Continuity Management, Strategic Advantage, Organization Structure, Private Securities and Organization Resources

\section{Introduction}

Strategy and business continuity management have been evolving as separate concepts over the last few decades in the international, regional and local arenas. Strategic planning as a critical instrument of management assists organizations to deal with numerous forces within their scopes and connect strategic goals with both mid-term and short-term plans. Business continuity management on the other hand guarantees self-assurance and aids the organization endure business discontinuities and interruptions [11].

The concepts of strategic planning and business continuity management have gained momentum thus widely embraced in recent years. Globally, this has been attributed to many factors such as natural disasters, business risks and other extreme happenings like terrorist activities that have led to more emphasis on the significance of strategic planning and business continuity management [33]. Such aforementioned risks and occurrences have had obvious tragic consequences and continued business investments disruptions/loss and even business 'deaths' or collapse or closure. Further, these have left most executives faced with the challenge of improving on the continuity strategies of their businesses and normal organizational lives. Alignment of strategic goals and continuity plans to remain relevant and mitigate against losses that may be incurred such as loss of investments in 
terms of employees, offices, equipment among others is now the worry of many business owners and managers.

The importance of having a protected and strategic plan for unlikely event that may interrupt normal functioning of an organization continues to be critical in many contemporary organizations. Organizational potential to interruptions and risk that have the potential to threaten the short and long-term existence of any business organization still receives little attention in strategic management research even though risk is one of the characteristics of organizations operating in vibrant and fast changing business environments.

\section{Theoretical Orientation}

The theories that were used for this study include the contingency theory and the resource based view theory.

\subsection{Contingency Theory}

In the 1970's contingency theory played a leading role in the organizational practice. According to [16] contingency theory is an approach to the study of organizational behavior in which explanations are given as to how contingent factors such as technology, culture and the external environment influence the design and function of organizations. The principle behind contingency theory is that no single type of organizational structure is equally applicable to all organizations. [5] reiterate that the theory tries to demonstrate that different circumstances require different organizational structures. Rather, organizational effectiveness is dependent on a fit or match between the type of technology, environmental volatility, the size of the organization, the features of the organizational structure and its information system [16].

A study by [9] asserts that contingency theory supposes that under different circumstances different solutions may prove effective. [23] argues that it typically examined the relationship between organizational structure and the operating conditions using the method of empirical comparative analysis. This methodical approach emphasizes the interaction between the organization and the environment and the importance of adaptation to the environment. Therefore, from structural point of view, the contingency theory observes the organization in terms of the environment, the organizational size and the strategic plan of the organization as contingency factors. Furthermore, [31] study hypothesized that a firm's structure was contingent on contextual factors such as technology, dimensions of task environment and organizational size. Therefore, as [10] states, the most effective organizational characteristics are those that fit the contingency variables. For instance, specialization in an organization produces highest performance when it fits the size of the organization, that is, the level of that contingency variable. Hence, highest performance results from low specialization in an organization of small size, whereas for an organization of large size, highest performance results from high specialization.

\subsection{Resource Based View Theory}

The RBV was developed as a complement to the industrial organization (IO) view. The proponents of the resource based view (RBV) argue that it is not the environment but the resources of the organization, which form the foundation of the firm's strategy [12]. The origins of the resource-based view can be traced back to several authors but [33] asserts that the fundamental principle of this theory lies based on a competitive advantage of an organization through the application of the bundle of valuable resources at the organization's disposal. The resources also must fulfill the VRIN criteria of being valuable, rare, in-imitable and nonsubstitutable in order to achieve a sustainable advantage. Its central proposition is that if a firm is to achieve a state of SCA it must acquire and control valuable, rare, inimitable, and non-substitutable (VRIN) resources and capabilities, plus have the organization in place that can absorb and apply them.

The RBV theory explains dissimilar nature of the firms because what contributes to resource limitations increase variations in company strategies [6]. Further, the theory suggests that, as resources become redundant companies must continually reinvent themselves through growth and investments, taking advantage of early adoption, deploying resources in sequence as they develop.

\subsection{Literature Review}

Literature review was done under the following subthemes;

\subsubsection{Organizational Structure and BCM}

Extant literature suggests existence of numerous components of an effective strategic plan and how to advance one. It is also on record that a lot of debates on pandemic readiness and potential threats highlight the need to outline and put into context vital communication and business corridors in the event of a [7]. From the discussion, BCM has emerged as the essential part to overall organization health that all sectors of business identify. However, with the international integration of private security business practices there is a greater potential for business interruption, as companies make effort to align structures, systems, style and resources into unified business entities. Thus, in any organization of the $21^{\text {st }}$ century, there need to be a clearly outlined BCM strategy within a strategic plan since it forms the basis for business performance and thus strategic to the long-term health of the firm.

The findings of [19] argued that structure dictates how policies, objectives are established and resource allocation. There is no one optimal organizational design or structure for a given strategy. They argued that when an organization changes its strategy, the existing organizational structure may become ineffective. They further highlighted that symptoms of an ineffective organizational structure include too many people, too much attention being directed towards solving conflicts, too large a span of control and too many 
unachieved objectives. Changes in structure should not be expected to make a bad strategy good or to make a bad manager good.

There exist different roles required to successfully practice business continuity management and include amongst other executives, boards and committees. [13] recognize the roles to be at an executive level, which include the chief executive officer (CEO) who is vested with all the responsibility of $\mathrm{BCM}$. Others are the chief financial officer (CFO) and the chief information officer (CIO) who report to the CEO. Availability of financial support to fund business continuity management initiatives is ensured by the CFO. All the role players are assigned to specific groups and committees created within the organization to work with. Then again, the manager in charge of BCM is responsible for assembling a team to execute the decisions made by the business continuity management steering committee [13]. The BCM manager presents vital decisions to business owners and should lead them during the recovery processes if a disruption has occurred. From the aforementioned, it is clear that the organization's executives should drive business continuity management. It is important to incorporate at all levels of the organization BCM so as employees can get involved in the BCM processes.

\subsubsection{Organizational Resources and BCM}

Organizations have at least four types of resources (human, capital, physical and time) that can be used to achieve desired result. [32] reiterate that BCM development and implementation has the following levels of involvement of key personnel or teams. They include general management (25\%), dedicated BCM department/person (16\%), information technology (20\%), risk management (12\%) and finance and accounting personnel (5\%). [19] noted that resource allocation is a central management activity that allows for strategy execution. The authors further highlighted that resources should be allocated according to priorities established by annual objectives. [30] highlighted that factors such as overprotection of resources, too great emphasis on short run financial criteria, organizational politics, vague strategy targets, a reluctance to take risks and lack of sufficient knowledge prohibit effective resource allocation.

Irrespective of the size of the organization, [29] state that different levels of human resources have a role in the strategic planning processes. This is because they may have input to the entire processes of strategy. Unlike large organizations which have different staff such as operational, sales and marketing, production, human resources, information technology and finance participate in strategic planning, family owned companies for instance, have all their strategies determined by the owner may [29].

Generally, most organizations have inadequate resources to run efficiently. They mostly operate on a tight budget each financial year. These budgets are adjusted accordingly to meet actual budgeted income and expenses. Any new income generated is invested and lack of funds means the organization will require loans to keep afloat [30]. Capital purchases that are planned for purchase always have their funds put aside for those purchases. Therefore, planning is vital that failure to plan may lead to unexpected failure of the organization. Top management has a strategic role to play to manage any business disruption of all the organization's departments as resources and priorities must be considered for not only an organizational survival but those of people and property in case of a disaster [20]).

It has also been argued that human resources of an organization play an important role to sustain the organizations competitive advantage and help develop a nexus with fruitful BCM [13]. Therefore, employees of an organization have tough tasks and/or responsibilities due to the ever-dynamic environmental pressures. In addition, the roles of managers and employers need to be clear [30]. Appropriate selection of employees within an organization is crucial to realize consistent productivity levels. Human resource planning and mobilization in terms of need ensures business improvement. The organization, allocation and timely mobilization have a positive impact on the smooth flow of business continuity management processes even in the event of adverse business environmental changes [30]. Research shows that human resources and planning have a distinct role in the organization, hence strategies being developed within the organization should include resource planning for effective deployment and utilization of humancapital resources that will translate to reliable economies of scale for financial stability and unmatched innovations that are unique and of value [30].

According to ISO 22301: 2012 standard, appropriate work force planning and organization is an important facet of organizational resource mobilization and that is a critical success factor of business continuity management hence leading to positive outcomes of organizational performance. Effective organizational performance is as a result of sustained competitive advantage [26]. Such a performance emanates from unique, valuable and non-substitutable resources which positively affect business continuity practices.

Sharing, transfer and access to tangible and intangible or information based resources with other networked individuals' in the organization has been associated with success and continuity of business [24]. Successful businesses survive only when employees have and effectively use the available scarce resources in order to seize opportunities and have the ability to contain possible risks and threats existing in the external business environment. Establishing joint interconnected networks or relationships for smooth resource mobilization is helpful for a business to get required resources such as physical, budgetary, financial, intellectual and technical in order to keeping the business running and continuously functional for its success [18]. This is because resource mobilization is hugely important and has a positive effect on business continuity management practices for steady functioning of the business.

Business disruptions whether natural or human made, can lead to discontinuity and interruptions of normal operations 
in an organization. This can adversely affect BCM processes if there is lack of effective mobilization of organizational resources to restore business normality. Delays may impact negatively on realization of business continuity management practices and ultimately the ongoing continuity of the business [30]. The authors' further state that delays in the scheduling, relocation and deployment of employees and other organizational resources in the organizational building may lead to business to stop or close. However much it may be stressful to deploy, move, relocate, restore, and recover etc. resources in a post-crisis stage to restore normal functional and operational continuity of the business, [14] state that it needs efficiency and planned proactivity in the mobilization of resources and equipment/facilities to their usual locations. This in turn will have a positive influence on business continuity management practices during business recovery and revamp. It also needs formal awareness of all the employees about the points and locations where they need to move and be available on the time. Rauch and others state that resource mobilization as an important supportive element of positive direction of business in order to sustain long-term continuity and persistent growth in firms [27].

\subsubsection{Relationship Between BCM and Organizational Success}

Many studies have been conducted on managing business continuity and its relation to organizational success. According to the study that was conducted by [2], the findings revealed that getting to know the likelihood and impact of eminent business disruption events can enhance organizational success. In a study by [4], BCM is exercised by organization to minimize adverse effects and impacts of internal and external risks that may affect its activities and performance. Similarly, a study by [15], found out that BCM must be managed the same way an organization manages risk management which is considered also as the origin of BCM. $\mathrm{BCM}$ is seen to be important because it plays an important role that may contribute to the optimization of organizational performance. $[17,28]$ added that management of risks also supports organizations in responding to uncontrollable market conditions to sustain consistent profitability, which eventually leads to optimized organizational performance.

Recent literature from studies by scholars for example [2] focused on the strategic role of BCM. The findings revealed that $\mathrm{BCM}$ can provides a competitive advantage on organizations that apply it. However, these studies have not done more investigations on how BCM could influence organizational success. Studies have established that issues relating to BCM and firm success were under researched. His study involved the banking sector in Jordan with a specific focus on the influence of BCM on a number of elements of organizational performance including profitability, effectiveness, efficiency, quality, innovation, productivity and quality of work-life highlighted the worth of strategic planning and BCM. The study findings further revealed that banking operations and critical business functions are preserved uninterrupted before, during and after an unexpected incident thus continuity of business.

\section{Methodology}

The study will employ a mixed methods design where both qualitative and quantitative research paradigms will be used for the purposes of extent and gravity of understanding and validation [19]. For the purpose of this study and to aid the achievement of the stated objectives, the target populations was two categories of staff in the private security firms in Kenya selected i.e. CEO/Owners/ Director and other employees - senior level managers in the firms.

\section{Results from the Findings}

From the study, it was found out that most companies/institutions under study did not have a written strategic plan but rather it was practiced frequently on a daily basis as employees worked under rules set for the work environment. This was according to explanation by one respondent Chatterjee, 2008, said that, in any organization of the $21^{\text {st }}$ century, there need to be a clearly outlined BCM strategy within a strategic plan since it forms the basis for business performance and thus strategic to the long-term health of the firm. Companies involved in the research practiced strategic management and planning. Most of them according to $30.3 \%$ of the respondents had existed for 610 years and many others having existed for more than 20 years as indicated by $27.4 \%$ of the respondents.

The strategic planning dimensions used in the study by the researcher were categorized into four: organization structure, organization system, and organization style and organization resources. Organization structure was discussed based on key elements that make up a structure. These elements were given to respondents who used them to rate their contribution to success of BCM. Therefore, BCM was discussed and supported by respondents in organization structure based on authority. Departmental coordination (87.2\%), developed strategy to achieve its purpose $(88 \%)$, and roles by management team, high achievement orientation, diversity of management team and its values. Organization system was another element under discussion for BCM. the respondents agreed that there was an adequate system to carry out administrative procedures $(80 \%)$, had a system to identify problems, had a system for analyzing opinions, spirit of open communication and how decisions are communicated to all and relevant people in a timely manner.

The resources of the organization were limited to human capital $(58.9 \%)$, the companies' capital for funding long term processes $(60.6 \%)$, ICT infrastructure and how it assists to achieve organizational goals. The resources also included skills and assignments designated to people (83.8\%), and not forgetting their competence to perform duties respectively. according to [29] Irrespective of the size of the organization, different levels of human resources have a role in the strategic planning processes. This is because they may have input to the entire processes of strategy. 
Organizational style majorly dealt with leadership by management of the companies. Here the elements of style included decision making that was centralized within the organization, commitment by managers. Majority of respondents $(70.5 \%)$ indicated that they used autocratic leadership style to help the company's focus on long term strategies that is emphasized through long-term health relationship with stakeholders as supported by [19], who said that there need to be a clearly outlined BCM strategy within a strategic plan since it forms the basis for business performance and thus strategic to the long-term health of the firm.

Majority of the respondents agreed that their companies have been involved in business continuity management of which most of them had been conducting BCM between 1-5 years. It was further revealed that senior management took charge of the business continuity processes in companies as agreed by some of the respondents. A small of the interviewees also agreed that the board of directors were responsible in steering business continuity management. This simply means that the top management of an organization is responsible for BCM success or failure.

The researcher also wanted to find out how elements of $\mathrm{BCM}$ are rated in companies effectively.it was clear that employees were engaged for effective BCM. This was in accordance with the opinion of majority of the respondents. The company extensively engaged company infrastructure to ensure effective BCM, they engaged customers and suppliers as well as facilities/premises for effective BCM.

\subsection{Inferential Statistics}

Table 1. Descriptive Statistics on Organizational Structure and BCM.

\begin{tabular}{llll}
\hline & Mean & Std. Deviation & N \\
\hline Average BCM & 1.2465 & .43249 & 142 \\
Average organization structure & 1.8803 & .65214 & 142 \\
\hline
\end{tabular}

Table 2. Correlation of organizational Structure and BCM.

\begin{tabular}{llll}
\hline & & Average BCM & Average organization Structure \\
\hline & Pearson Correlation & 1 & $.382^{* *}$ \\
Average BCM & Sig. (2-tailed) & & .000 \\
& $\mathrm{~N}$ & 142 & 142 \\
Average organization Structure & Pearson Correlation & $.382^{* *}$ & .000 \\
& Sig. (2-tailed) & 142 & 142 \\
\hline
\end{tabular}

**. Correlation is significant at the 0.01 level (2-tailed).

The findings revealed that organizational structure has a positive significant relationship with business continuity management of private security companies

Table 3. Descriptive Statistics on Organizational Resources and BCM.

\begin{tabular}{llll}
\hline & Mean & Std. Deviation & N \\
\hline Average BCM & 1.2465 & .43249 & 142 \\
Average organization Resources & 2.1894 & .78701 & 142 \\
\hline
\end{tabular}

Table 4. Organizational Resources and BCM Correlations.

\begin{tabular}{llll}
\hline & & Average BCM & Average Organization Resources \\
\hline & Pearson Correlation & 1 & $.331^{* *}$ \\
Average BCM & Sig. (2-tailed) & .000 & 142 \\
& $\mathrm{~N}$ & 142 & $.331^{* *}$ \\
Average Organization Resources & Pearson Correlation & .000 & 1 \\
& Sig. (2-tailed) & 142 & 142 \\
\hline
\end{tabular}

**. Correlation is significant at the 0.01 level (2-tailed).

Organizational resources have a positive significant relationship with business continuity management of private security firms in Kenya.

Table 5. Regression analysis Coefficients.

\begin{tabular}{|c|c|c|c|c|c|}
\hline \multirow{2}{*}{ Model } & \multicolumn{2}{|c|}{ Unstandardized Coefficients } & \multirow{2}{*}{$\begin{array}{l}\text { Standardized Coefficients } \\
\text { Beta }\end{array}$} & \multirow{2}{*}{$\mathbf{t}$} & \multirow{2}{*}{ Sig. } \\
\hline & B & Std. Error & & & \\
\hline (Constant) & .494 & .120 & & 4.116 & .000 \\
\hline Average of organization Structure & .152 & .060 & .228 & 2.532 & .012 \\
\hline Average of organization resources & .091 & .049 & .165 & 1.851 & .066 \\
\hline
\end{tabular}

a. Dependent Variable: Overall BCM. 
There is a significance difference between the business continuity management and the following; organizational structure, organizational resources, BCM components and the organization systems.

$$
\mathrm{Y}=0.494+0.152 \mathrm{X} 1+0.091 \mathrm{X} 2 \times 0.12
$$

Table 6. Communalities on Factor Analysis.

\begin{tabular}{|c|c|c|}
\hline & Initial & Extraction \\
\hline The company is authoritative in how it handles aspects of its operations & 1.000 & .825 \\
\hline There is good co-ordination across departments & 1.000 & .746 \\
\hline The company has a well-developed strategy to achieve its purpose & 1.000 & .656 \\
\hline The company has a clearly defined purpose to which all concerned are committed & 1.000 & .675 \\
\hline The organizations top management team members identify their own roles with organizational strategy? & 1.000 & .613 \\
\hline The organizations top management team shows high achievement orientation? & 1.000 & .745 \\
\hline The organizations top management team is diverse in nature? & 1.000 & .619 \\
\hline The company has adequate systems to carry out administrative procedures & 1.000 & .657 \\
\hline The organization has a system for identifying problems? & 1.000 & .650 \\
\hline The organization has a system for analysing opinions, thus taking relevant decisions & 1.000 & .769 \\
\hline The company has a spirit of open communication & 1.000 & .611 \\
\hline All company decisions are communicated to all and relevant people in a timely manner & 1.000 & .713 \\
\hline There are effective systems of monitoring and evaluation of strategy & 1.000 & .794 \\
\hline
\end{tabular}

Extraction Method: Principal Component Analysis.

Table 7. Total Variance Explained.

\begin{tabular}{|c|c|c|c|c|c|c|c|c|c|}
\hline \multirow{2}{*}{ Component } & \multicolumn{3}{|c|}{ Initial Eigenvalues } & \multicolumn{3}{|c|}{ Extraction Sums of Squared Loadings } & \multicolumn{3}{|c|}{ Rotation Sums of Squared Loadings } \\
\hline & Total & $\%$ of Variance & Cumulative \% & Total & $\%$ of Variance & Cumulative \% & Total & $\%$ of Variance & Cumulative \% \\
\hline 1 & 9.381 & 34.745 & 34.745 & 9.381 & 34.745 & 34.745 & 4.172 & 15.453 & 15.453 \\
\hline 2 & 2.116 & 7.838 & 42.584 & 2.116 & 7.838 & 42.584 & 3.107 & 11.507 & 26.960 \\
\hline 3 & 1.547 & 5.729 & 48.313 & 1.547 & 5.729 & 48.313 & 2.316 & 8.579 & 35.539 \\
\hline 4 & 1.430 & 5.296 & 53.610 & 1.430 & 5.296 & 53.610 & 2.268 & 8.400 & 43.940 \\
\hline 5 & 1.233 & 4.568 & 58.177 & 1.233 & 4.568 & 58.177 & 2.211 & 8.187 & 52.127 \\
\hline 6 & 1.149 & 4.256 & 62.433 & 1.149 & 4.256 & 62.433 & 1.653 & 6.122 & 58.249 \\
\hline 8 & 1.004 & 3.720 & 69.901 & 1.004 & 3.720 & 69.901 & 1.515 & 5.612 & 69.901 \\
\hline
\end{tabular}

Extraction Method: Principal Component Analysis.

Table 8. Rotated Component Matrix ${ }^{a}$

\begin{tabular}{|c|c|c|c|c|c|c|c|c|}
\hline & \multicolumn{8}{|c|}{ Component } \\
\hline & 1 & 2 & 3 & 4 & 5 & 6 & 7 & 8 \\
\hline The organizations top management team shows high achievement orientation? & .807 & & & & & & & \\
\hline The organizations top management team is diverse in nature? & .710 & & & & & & & \\
\hline The organizations top management team members identify their own roles with organizational strategy? & .670 & & & & & & & \\
\hline The organization's top management team shares same values concerning the way it operates? & .604 & & & & & & & \\
\hline The company has a well-developed strategy to achieve its purpose & .576 & & & & & & & \\
\hline The company has a clearly defined purpose to which all concerned are committed & .549 & & & & & & .400 & \\
\hline This company has adequate capital and/or funding resources to sustain it in the long-run & & .797 & & & & & & \\
\hline This company has adequate human capital & & .747 & & & & & & \\
\hline
\end{tabular}

Extraction Method: Principal Component Analysis.

Rotation Method: Varimax with Kaiser Normalization.

a. Rotation converged in 10 iterations.

The table above shows the factors arranged from the ones with higher factor loading to the least. The findings revealed that the first component that affect business continuity management include the following factors. The organizations top management team shows high achievement orientation; The organizations top management team is diverse in nature; The organizations top management team members identify their own roles with organizational strategy; The organization's top management team shares same values concerning the way it operates; The company has a welldeveloped strategy to achieve its purpose and that the company has a clearly defined purpose to which all concerned are committed. This showed that the organization structure had a high influence on business continuity management.

The Second components included; The Company's existing Information technology (ICT) infrastructure assists in achievement of organizational goals and objectives; the company has adequate capital and/or funding resources to 
sustain it in the long-run and that the company has adequate human capital. The findings revealed that Organization Resources were the second factors that affected business continuity management. Resources were seen as being another key contributor to business continuity management.

\section{Conclusion}

BCM has emerged as the essential part to overall organization health that all sectors of business identify.it is clear that BCM success depends on clearly defined strategic plans through planning by management. Management planning was regarded as strongly important by the respondents. The strategic plans are laid down by the management of an organization which is defined by several elements in practice. The elements are categorically based on the organization structure, style, system and resources. Therefore, business continuity management is a combination of different elements of the organization. According to [3], it is important to combine organizational and financial resources with all strategic planning and implementation processes and make them available in the event of an emergency [3] for business continuity purposes.

\section{References}

[1] Akram Jalal Karim, A. J. (2011). Business disaster preparedness: an empirical study for measuring the factors of business continuity to face business disaster. International Journal of Business and Social Science, 2 (18):183-192.

[2] Alesi, P. (2008), Building enterprise-wide resilience by integrating business continuity capability into day-to-day business culture and technology. Journal of Business Continuity and Emergency Planning, 2, 214-220.

[3] Almarri, K., \& Gardiner, P. (2014). Application of resourcebased view to project management research: supporters and opponents. Procedia-Social and Behavioral Sciences, 119: 437-445.

[4] Bakar, Z. A., Yacoob, N. A., \&Udin, Z. M. (2015). The Effect of Business Continuity Management Factors on Organizational Performance: A Conceptual Framework. International Journal of Economics and Financial Issues, 5 (Special Issue): 128-134. Retrieved August 21, 2015 from: http: www.econjournals.com.

[5] Baranyi, Á. (2001). Environmental strategy types used by Hungarian manufacturing Companies. ( $\mathrm{PhD}$ thesis). $\mathrm{PhD}$ Program: BKÁE.

[6] Berrone, P., Gelabert, L., Fosfuri, A. \& Gömez-Mejia, L. R. (2007). Can institutional forces create competitive advantage? Empirical examination of environmental innovation. Working Paper No. 723. IESE Business School: University of Navara. Retrieved on August 19, 2015 from http://www.www.iese.edu/research/pdfs/DI-0723-E.pdf.

[7] Chatterjee, B. (2008). Integrating business continuity as part of strategic planning. Retrieved on August 19, 2015 from http://www.cemag.us/articles/2008/04/integrating-businesscontinuity-part-strategic-planning.
[8] Díaz-García, M. C., \& Carter, S. (2009). Resource mobilization through business owners' networks: is gender an issue? International Journal of Gender and Entrepreneurship, 1 (3): $226-252$.

[9] Dobák, M., \& Antal, Z. (2010). Management and organization: creating and operating organizations. Aula Kiadó: Budapest.

[10] Donaldson, L. (2008). Contingency theory (structural). Retrieved on August 19, 2015 from http://dx.doi.org/10.4135/9780857020109.n25.

[11] Elliott, D. Swartz, E. \& Herbane, B. (2010). Business continuity management: a crisis management approach. New York: Routledge.

[12] Feurer, R., \& Chaharbaghi, K. (1997). Strategy development: past, present and future. Training for Quality, 5 (2):58-70. Retrieved August 29, 2015 from http://dx.doi.org/10.1108/09684879710167647.

[13] Graham, J. \&Kaye, D. 2006. A risk management approach to business continuity. Brookfield, Connecticut USA: Rothstein Associates Inc.

[14] Hassanain, M. A., \& Al-Mudhei, A. (2006). Fire safety evaluation of motor fuel dispensing facilities. Structural Survey, 24 (1): 65-76.

[15] Hyman, L., Lamb, J., \& Bulmer, M. (2006). The use of preexisting survey questions: implications for data quality. Proceedings of Q2006 European Conference on Quality in Survey Statistics. Retrieved August 30, 2015 from ec.europa.eu/...surveyquestions.../e953a39e-50be-40b3-910f-6c0d83f5.

[16] Islam, J., \& Hu, H. (2012). A review of literature on contingency theory in managerial accounting. African Journal of Business Management, 6 (15):5159-5164. DOI: 10.5897/AJBM11.2764.

[17] Jafari, M., Chadegani, A., Biglari, V. (2011). Effective risk management and company's performance: investment in innovations and intellectual capital using behavioural and practical approach. International Research Journal of Finance and Economics, 3 (15):780-786.

[18] Johannisson, B. (1995). Paradigms and entrepreneurial networks-some methodological challenges. Entrepreneurship and regional development, 7 (3): 215-232.

[19] Johnson, R. B., Onwuegbuzie A. J. \& Turner, L. A. (2007). Toward a definition of mixed methods research. Journal of Mixed Methods Research, 1 (2):112-133. Available at: http://mmr.sagepub.com. DOI: 10.1177/1558689806298224.

[20] Karim, A. J. (2011). Business Disaster Preparedness: An Empirical Study for measuring the Factors of Business Continuity to face Business Disaster. International Journal of Business and Social Science, 2 (18): 183-192. Accessed from www.ijbssnet.com.

[21] Lam, W. (2002). Ensuring business continuity. IT Professional, 4 (3):19-25.

[22] Malhotra, N. K., Hall, J., Shaw, M. \& Oppenheim, P. (2002). Marketing Research: An Applied Orientation, Prentice-Hall, Sydney.

[23] Matyusz, Z. (2012). The effect of contingency factors on the use of manufacturing practices and operations performance. (Unpublished PhD Thesis). Institute of Business Economics, Corvinus University of Budapest. Retrieved on August 19, 2015 from http://www.phd.lib.unicorvinus.hu/655/2/Matyusz_Zsolt_den.pdf. 
[24] Neergaard, H., Shaw, E., \& Carter, S. (2005). The impact of gender, social capital and networks on business ownership: a research agenda. International Journal of Entrepreneurial Behavior and Research, 11 (5): 338-357.

[25] Porter, M. E. (2004). Competitive strategy. In B. de Wit and R. Meyer (eds.), Strategy process content, context: an international perspective. Thomson Learning: London, pp. 258-262.

[26] Priem, R. L., \& Butler, J. E. (2001). Is the resource based "view" a useful perspective for strategic management research? Academy of Management Review, 26 (1): 22-40.

[27] Rauch, A., Wiklund, J., Lumpkin, G. T., \& Frese, M. (2009). Entrepreneurial orientation and business performance: An assessment of past research and suggestions for the future. Entrepreneurship Theory and Practice, 33 (3): 761-787.

[28] Saleem, S. (2011), Do effective risk management affect organizational performance. European Journal of Business and Management, 3 (3), 258-268.

[29] Scott-Martinet, K. (2006). Strategic contingency planning. Unpublished MSc thesis in emergency services administration,
University of Hawaii, West Oahu. Accessed from https://training.fema.gov/.../scott-martinet\%20-\%20abstractstrategic $\% 20 \ldots$

[30] Shuja, A. \& Abbasi, A. s. (2015). An investigation of the impact of resource mobilization on business continuity management: a study on banking sector of Pakistan. Science International (Lahore), 27 (3): 2551-2558. Retrieved on February 24, 2016 from www.sci-int.com/.../2142185562551$2558 \% 20$ Aleena $\% 20$ Shuja $\% 202++\ldots$

[31] Sundström, G. \& Hollnagel, E. (2006). Learning how to create resilience in business systems. In Hollnagel, E., Woods, D. D. \& Leveson, N. (eds.). Resilience engineering: concepts and precepts. Aldershot, UK: Ashgate.

[32] Verman, A. G. (2011). Business continuity planning in the IT age: a railway sector case study. Journal of Business Management, 3 (5): 11-36.

[33] Wessels, E. (2007). Towards a framework for business continuity management: an IT governance perspective. (Unpublished Maste-Informatics thesis). Available at: http://up.etd. 